УДК 002.2:378.4(477-25) КНУКіМ (049.32)

Горбань Юрій Іванович, кандидат культурології, доцент кафедри інформаційних технологій, директор наукової бібліотеки Київського національного університету культури і мистецтв y.i.gorban@gmail.com ORCID: https://orcid.org/0000-0001-5837-4409

\title{
АНТОЛОГІЯ «КНИГОЗНАВЧА ШКОЛА КИЇВСЬКОГО НАЦІОНАЛЬНОГО УНІВЕРСИТЕТУ КУЛЬТУРИ І МИСТЕЦТВ» У НАУКОВОМУ ЖИТТІ УКРАЇНИ КІНЦЯ ХХ - ПОЧАТКУ ХХІ СТ.
}

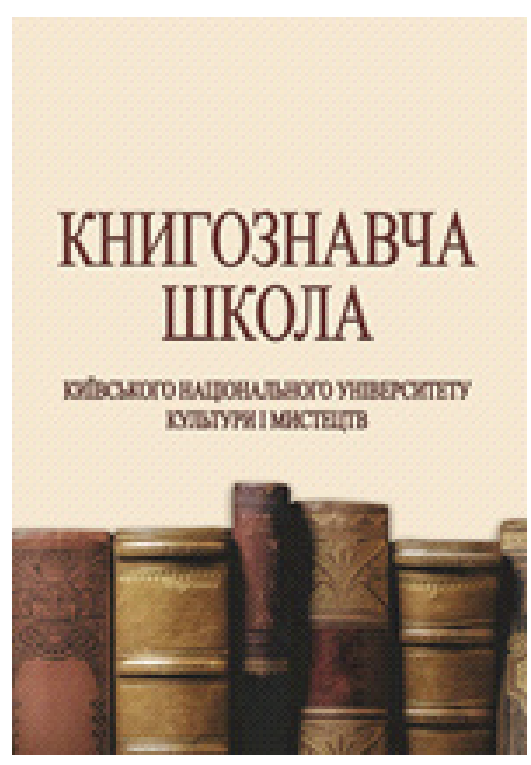

У сучасному суспільстві знань стратегічно важливого значення набуває розвиток науки, підвищення результативності фундаментальних та прикладних досліджень як окремих вчених, так і наукових колективів, наукових шкіл.

За останні 20 років нові політичні, економічні та соціальні умови спричинили розвиток недержавної книжкової справи, кардинальні зміни динаміки й структури книжкового потоку, поширення електронних видань. Ці новації вплинули й на стан та розвиток книгознавства. Ще більше значення мали зміни в організації науки й друку. Перш за все, мова йде про скасування цензури та інших політичних обмежень, що сприяло появі нових напрямів в книгознавстві. Нові реалії потребують подальшої розробки теорії та методології книгознавства, бібліотекознавства та бібліографії.

Представлена антологія - перше оригінальне наукове видання, що формує у читача цілісне уявлення про сучасний книгознавчий 
процес, інтелектуальні здобутки книгознавчого, бібліотекознавчого і бібліографознавчого напрямів на основі викладу думок науковців Київського національного університету культури і мистецтв, Національної академії керівних кадрів культури і мистецтв, Київського університету імені Бориса Грінченка, Національної бібліотеки України імені В. І. Вернадського НАН України та інших установ культури та освіти.

Дотепер в Україні була знаною лише Харківська наукова школа книгознавства, бібліотекознавства і бібліографії, відома своїми багатими традиціями та науковими досягненнями, що визнані не лише в Україні, а й за кордоном.

Антологія складається зі слова до читача, семи розділів, післямови, відомостей про авторів антології, переліку дисертацій, захищених у КНУКіМ, списку умовних скорочень.

У слові до читача М. М. Поплавський, доктор педагогічних наук, професор, президент Київського національного університету культури і мистецтв, заслужений працівник культури України зазначає, що книгознавча школа Київського національного університету культури і мистецтв формується в умовах складної і неоднозначної сучасної культурної, ідеологічної, економічної, освітньої ситуації і перебуває на своїй ранній стадії становлення. Доктор філософських наук, професор Київського національного університету культури i мистецтв С. Д. Безклубенко також звертається до читачів та наголошує, що серія видань, зазначених на титульному аркуші, i має на меті ознайомити широку громадськість із науковими школами КНУКіМ шляхом розповіді про їх представників. I перший випуск цієї серії «по праву первородства» присвячується книгознавцям вишколу Київського національного університету культури і мистецтв. Ще один корифей науки, кандидат педагогічних наук, професор Київського національного університету культури і мистецтв, заслужений працівник культури України В. М. Медведєва впевнена, що сьогодні, як ніколи, постала потреба осмислення ролі науки у формуванні та вдосконаленні сучасної цивілізації. На цьому все більше наголошує світова наукова спільнота під час міжнародних форумів. Особливо це стосується пострадянських країн, де посилюються негативні тенденції ставлення до науки з боку державних органів влади, загалом суспільних чинників.

До антології включені відомості, основні публікації та фрагменти статей видатних українських вчених в галузі книгознавства, бібліотекознавства та бібліографії, що дозволяє створити панораму актуальних книгознавчих ідей в Україні.

Перший розділ «Теоретичні засади книгознавства, бібліотекознавства, бібліографознавства» присвячений теоретико-методичним засадам бібліотекознавства, інформаційної справи, бібліотеці в системі соціальних комунікацій, книгознавчим концепціям, розвитку бібліотекознавства. В ньому представлені відомості та статті відомих вчених, таких, як: Воскобойнікова-Гузеєва О.В.(Соціальне партнерство у розвитку бібліотечно-інформаційної сфери України), Гранчак Т. Ю. (Бібліотека у політичній комунікації), Долбенко Т. О. (Стандарт вищої освіти в контексті змісту підготовки бібліотечних кадрів), Новальська Т. В. (Розвиток спеціального бібліотекознавства в структурі вітчизняної науки), Тимошик М. С. (Дискусія, спрямована на вчорашній день. Що стоїть за берегами організованої на сторінках «Вісника книжкової палати» нової полеміки щодо витоків української книги?) та ін.

У другому розділі «Книжкова справа України» (історичний розвиток бібліотек, історія книги, редакційно-видавнича справа, книжкова торгівля) увагу зосереджено на ролі бібліотек навчальних закладів, книгорозповсюдженні, проблемах стандартизації, книгознавчої культури. Розділ складають праці Гурбанської А. I (Видання книг поетичних творів Ліни Костенко в Україні та за кордоном у 1950 - 70-х роках), Каракоз О. О. (Цензура як засіб ідеологічного впливу на формування фондів публічних бібліотек України у 20-х рр. ХХ ст.), Кочубей Л. О. (До започаткування книжковою палатою України електронного реферативного часопису «Історія. Історичні науки»), Салати Г. В. (Глобалізація предметної області бібліотечноінформаційної галузі на прикладі діяльності публічних бібліотек України) та ін.

Розділ третій «Бібліографознавство» охоплює питання національної бібліографії, 
місця бібліотеки в інформаційному просторі, фондів бібліотек, особливостей підготовки бібліографів-краєзнавців, професійної комунікації. Наповнений розділ статтями Бабича В. С. (До проблеми підготовки кадрів бібліотечно-інформаційної сфери), Геращенка М. В. (Т. Г. Шевченко в російській дожовтневій бібліографії (до 200-річчя від дня народження Кобзаря)), Дяченко Н. С. (Формування системи рекомендаційних бібліографічних посібників для дітей в Україні в 90-ті роки XX ст.), Кащук O. I. (Самостійна робота та використання технічних засобів навчання студентами бібліотечного факультету при вивченні курсів галузевих бібліографічних дисциплін) та ін.

Зміст четвертого розділу «Документноінформаційні ресурси» висвітлює проблеми зберігання книжкових пам'яток, професійної компетентності, формування фондів електронних бібліотек, оптимізації інформації. Представленні основні дані та статті Грінберг Л. Ф. (Професійна компетентність як показник рівня професіоналізму майбутніх документознавців), Кириленка О. Г. (Прикладні аспекти використання інформаційного моніторингу в системі підготовки документознавців), Петрової М. В. (Роль інформаційнокомунікаційної системи управління у моделюванні пріоритетних напрямів діяльності бібліотеки), Сидоренко А. I. (Документний потік України мовами національних меншин: стан і тенденції розвитку) та ін.

П'ятий розділ «Бібліотека i читач в документно-інформаційній системі суспільства» репрезентує сучасні концепції вітчизняного та зарубіжного бібліотекознавства, особливості бібліотечного обслуговування, питання іміджу бібліотек, соціокультурну діяльність бібліотек, інноваційні технології в професійному навчанні бібліотекарів, інформаційні потреби користувачів. В розділі можна знайти інформацію та роботи таких науковців, як Бачинська Н. А. (Кадри сільських бібліотек: проблеми та перспективи), Зніщенко М. П. (Про «націоналізм» і «шкідництво» в бібліотечній справі на сторінках часопису «Бібліотеки у соціалістичному будівництві». Рік 1934: погляд із XXI ст.), Іванова I. Ф. (Професійна ідентичність та індивідуальні психологічні особливості студентів), Новіко- ва Н. О. (Дитячі бібліотеки України як компонент культури (історіографія дослідження), Прокопенко Л. І. (Становлення та розвиток теорії інформаційних потреб користувачів документно-інформаційних установ), Шуляк С. О. (Використання сучасних ігрових форм у бібліотечно-інформаційному обслуговуванні читачів дитячих бібліотек) та ін.

У шостому розділі «Управління діяльністю бібліотек. Інноваційно-методична робота» схарактеризовано та висвітлено питання організації та управління інформаційними установами в сучасних умовах, інноваційного управління бібліотекою, бібліотечного туризму. Наповнюють розділ статті Виноградової О. Б. (Організація діяльності бібліотеки як навчальна дисципліна: історія, перспективи викладання), Срмолаєвої Г. А. (Сучасні вимоги до керівних кадрів бібліотечної системи України (огляд результатів соціологічних досліджень дев'яностих років двадцятого та початку двадцять першого ст.)), Саприкіна Г. А. (Китай: бібліотеки, культура, мандри).

Головні теми сьомого розділу «Бібліотечно-інформаційна освіта, професійна комунікація» - бібліотечна соціологія, професійна комунікація у книжковій галузі, бібліотечна освіта. Зазначеними питаннями в галузі бібліотекознавства займаються Гич Г. М. (Витоки, сучасний стан та перспективи бібліотечної соціології), Матвієнко О. В. (Бібліотеки органів державної влади: специфіка завдань діяльності. Постановка проблеми та іiі зв'язок з практичними та науковими завданнями), Сошинська В. Є. (Трансформація каналів професійної комунікації в документно-інформаційній сфері), Трач Ю. В. (Культурологічний аспект розвитку інформаційних технологій у контексті глобалізації), Шевченко І. О. (Бібліотеки більше ніж бібліотеки).

Дисертації, захищені у Київському національному університеті культури і мистецтв (1994 - 2017 рр.) - це систематизований, розміщений у хронологічній послідовності перелік дисертацій з книгознавства, бібліотекознавства та бібліографії, що містить прізвище та ініціали дисертанта, тему, бібліографічний опис та загальні положення дисертаційного дослідження.

Аналіз сучасного стану книгознавства дозволяє констатувати, що нині ця наука зна- 
ходиться на початку нового етапу свого розвитку, що пов'язаний з глобальними змінами інформаційного простору. Проте будь-які нові віяння та напрями наукової думки не повинні заперечувати попередній досвід. Слід зазначити, що основні наукові школи книгознавства - Харківська, Рівненська - незмінно слідують принципам історизму та поважливого ставлення до результатів діяльності попередніх епох. Це дозволяє сподіватися на плідний розвиток науки про книгу в майбутньому.

Рецензована антологія «Книгознавча школа Київського національного університету культури і мистецтв» своєчасна, актуальна та грунтовна праця колективу авторів, яка висвіт- лює основні проблеми, питання книгознавства та пропонує шляхи розвитку бібліотечної справи. Це, в свою чергу, суттєво активізувало роботу і щодо осмислення процесів трансформації поняттєвого апарату, утвердження нової словникової бази. А це, безумовно, збагатило теоретико-методологічні підходи до виявлення проблем, розширило можливості включення у світовий науковий дискурс з урахуванням національної специфіки.

На думку автора, перспектива антологізації книгознавчого процесу є незаперечною. Такий досвід в сучасному літературному процесі цьому є свідченням.

\section{Список використаних джерел}

1. Книгознавча школа Київського національного університету культури і мистецтв: антологія / В. М. Медведєва. Київ : Видавництво Ліра-К, 2018. 676 с. 